\title{
ANALISIS BANJIR KELURAHAN TANJUNG DUREN SELATAN
}

\author{
Natanael Tadeus Sutanto ${ }^{1}$ dan Wati Asriningsih Pranoto ${ }^{2}$ \\ ${ }^{1}$ Program Studi Sarjana Teknik Sipil, Universitas Tarumanagara, Jl. Letjen S. Parman No.1 Jakarta \\ Natanael.325150024@stu.untar.ac.id \\ ${ }^{2}$ Program Studi Sarjana Teknik Sipil, Universitas Tarumanagara, Jl. Letjen S. Parman No.1 Jakarta \\ Watip@ft.untar.ac.id
}

\begin{abstract}
Flood is one of the natural disasters that occur due to various factors and causes many losses. Tanjung Duren Selatan village was recorded as having floods in January 2020. This research aims to determine the causes of the flood in the area as well as the solution. The data obtained were taken from BMKG, West Jakarta City Water Resources Department, and direct measurements in the review area. This research analyzed rainfall, channel capacity, channel condition dan topography in Tanjung Duren Selatan village. Rainfall is tested for data compatibility using Chi-Square and Kolmogorov-Smirnov methods. Rainfall intensity is calculated using the Mononobe formula. The capacity of the existing channels is analyzed using Manning formula that will be compared with the planned discharge calculated using Rasional method. The analysis included secondary channels and tertiary channels, based on the calculation of 8 of the 48 channels reviewed that were unable to accommodate the planned discharge. After the analysis, it can be concluded that the flooding in Tanjung Duren Selatan village was caused by the lack of existing channel capacity, contours, and rubbish that blocked the water flow. Floods that occurred on January 1, 2020 due to rainfall that occurred exceeded the planned rainfall.
\end{abstract}

Keywords: flood; drainage; Manning

\begin{abstract}
ABSTRAK
Banjir merupakan salah satu bencana alam yang terjadi akibat berbagai faktor dan menimbulkan banyak kerugian. Di Kelurahan Tanjung Duren Selatan tercatat mengalami banjir pada bulan Januari 2020. Penelitian ini bertujuan untuk mengetahui faktor penyebab terjadinya banjir pada daerah tersebut serta solusinya. Data-data yang didapat diambil dari BMKG, Suku Dinas Sumber Daya Air Kota Jakarta Barat, serta pengukuran langsung di daerah tinjauan. Pada penelitian ini dianalisis curah hujan, kapasitas saluran, kondisi saluran, serta topografi di Kelurahan Tanjung Duren Selatan. Curah hujan di uji kecocokan datanya menggunakan metode Chi-Square dan KolmogorovSmirnov. Intensitas curah hujan di hitung menggunakan rumus Mononobe. Kapasitas saluran eksisting di analisis menggunakan rumus Manning yang akan dibandingkan dengan debit rencana yang dihitung menggunakan metode Rasional. Analisis yang dilakukan mencakup saluran sekunder dan saluran tersier, berdasarkan perhitungan 8 dari 48 saluran yang ditinjau tidak mampu menampung debit rencana. Setelah analisis dilakukan dapat disimpulkan bahwa banjir di Kelurahan Tanjung Duren Selatan disebabkan oleh kurangnya kapasitas saluran eksisting, kontur, serta sampah yang menghalangi aliran air. Banjir yang terjadi pada tanggal 1 Januari 2020 dikarenakan curah hujan yang terjadi melebihi curah hujan rencana.
\end{abstract}

Kata kunci: banjir; drainase; Manning

\section{PENDAHULUAN}

Tanjung Duren Selatan merupakan kelurahan yang terletak di kecamatan Grogol Petamburan, Jakarta Barat, Daerah Khusus Ibukota Jakarta, Indonesia. Kelurahan Tanjung Duren Selatan sendiri memiliki luas 137 ha dengan jumlah penduduk 21.301 jiwa dan 4.029 kepala keluarga (Dinas Komunikasi, Informatika dan Statistik Pemprov DKI Jakarta, 2017). Di kelurahan Tanjung Duren Selatan sebagian besar daerahnya didominasi oleh pemukiman penduduk dan daerah perdagangan. Daerah ini mengalami genangan air dalam jangka waktu yang beragam lamanya akibat hujan yang terjadi pada tanggal 31 Desember 2019 sampai dengan tanggal 1 Januari 2020. Oleh karena itu perlu dianalisis untuk mencari tahu penyebab dan cara menanggulangi genangan air yang terjadi di Kelurahan Tanjung Duren Selatan tersebut. Berdasarkan Suku Dinas Sumber Daya Air Kota Jakarta Barat titik genangan air yang ada di Tanjung Duren Selatan pada 1 Januari 2020 dengan tinggi $15 \mathrm{~cm}$ pada Gambar 1. 


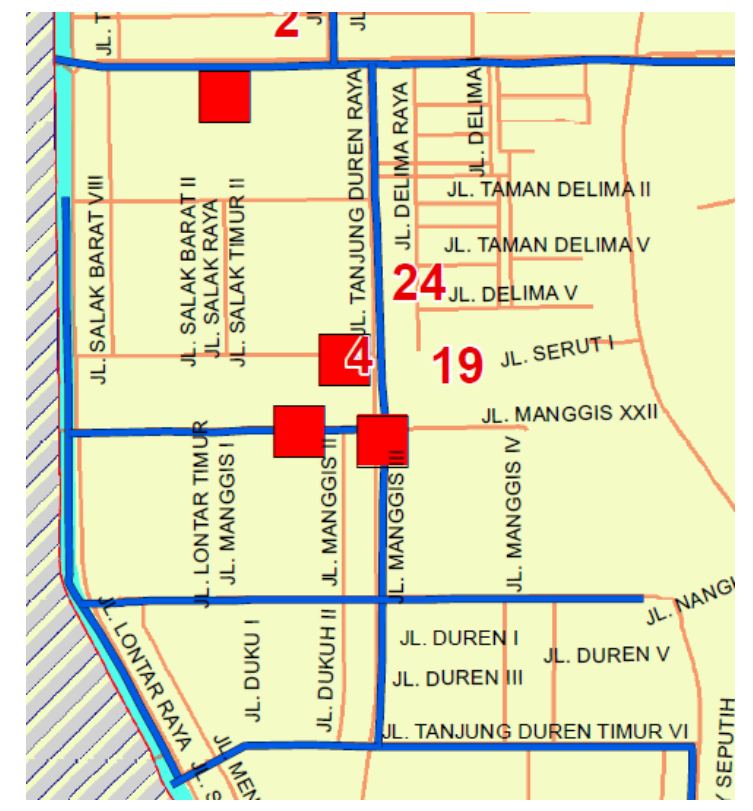

Gambar 1. Sebaran titik banjir Kelurahan Tanjung Duren Selatan

Dalam analisa ini akan difokuskan pada titik 4, 19, dan 24. Titik-titik tersebut dipilih karena memiliki genangan yang cukup tinggi.

Berdasarkan uraian yang dikemukakan diatas penulis merumuskan permasalahannya sebagai berikut:

1. Apakah kapasitas saluran eksisting dapat menampung debit air dengan curah hujan yang terjadi pada periode 31 Desember 2020 sampai dengan 1 Januari 2020?

2. Apakah kapasitas saluran eksisting dapat menampung debit air dengan curah hujan yang terjadi pada periode ulang 2 tahun, 5 tahun, 10 tahun, atau 25 tahun?

3. Apakah topografi di daerah yang tergenang menjadi faktor penyebab terjadinya genangan?

4. Apa upaya pencegahan yang dapat dilakukan agar banjir yang sama tidak terulang?

Berdasarkan rumusan masalah tersebut maka tujuan dari penelitian ini adalah sebagai berikut:

1. Mengetahui penyebab genangan air di Kelurahan Tanjung Duren Selatan.

2. Mengetahui apakah saluran drainase eksisting sudah mampu menampung debit rencana.

3. Mengetahui apa saja yang perlu dilakukan untuk mencegah terjadinya banjir yang sama terulang.

\section{Uji distribusi}

Jenis sebaran fungsi distribusi yang sering digunakan pada analisis frekuensi untuk hujan ekstrim di Indonesia adalah Pearson III, Log Pearson III, Gumbel Tipe 1, Normal, Log Normal 2, dan Log Normal 3 parameter (Badan Standarisasi Nasional, 2016).

\section{Uji Chi-Square}

Metode ini menganggap pengamatan membentuk variabel acak dan dilakukan secara statistik dengan mengikuti kurva distribusi Chi-Square dengan derajat kebebasan k-p-1, dengan p merupakan jumlah parameter yang diestimasi dari data. Uji statistik ini berdasarkan pada bobot jumlah kuadrat perbedaan antara pengamatan dan teoritisnya yang dibagi dalam kelompok kelas.

Jika hasilnya $X \frac{k}{n}$ besar menunjukkan bahwa distribusi yang dipilih tidak cocok, tetapi uji ini dapat memberikan hasil yang baik jika mempunyai data yang panjang. Kottegoda (1996) menyarankan sebaiknya $\mathrm{n} \geq 50$ tahun dan jumlah kelas interval $\geq 5$.

Urutan pemeriksaan kesesuaian distribusi adalah sebagai berikut:

1. Urutkan data pengamatan dari data kecil ke besar atau sebaliknya;

2. Kelompokkan data pengamatan menjadi beberapa " $k$ " kelas interval $(\mathrm{k}$ diambil $=5)$;

3. Catat frekuensi data pengamatan pada setiap kelas interval;

4. Hitung frekuensi kejadian yang diharapkan " $\mathrm{F"}$;

5. Hitung nilai $\mathrm{X}^{2}$; 
6. Tentukan nilai derajat kebebasan $\mathrm{D}_{\mathrm{k}}$;

7. Tetapkan besar tingkat kepercayaan (confidence level, misal 95\%);

8. Cari $\mathrm{X}^{2}$ kritis dari tabel harga kritis Chi-Square.

Bandingkan $X^{2}$ hitungan dengan $X^{2}$ kritis, Bila hitungan $X^{2}<X^{2}$ kritis, berarti metode distribusi yang diperiksa dapat diterima.

\section{Uji Kolmogorov-Smirnov}

Uji kecocokan ini merupakan uji kecocokan "non parametric" karena tidak mengikuti distribusi tertentu. Uji ini menghitung besarnya jarak maksimum secara vertikal antara pengamatan dan teoritis dari distribusi sampelnya. Distribusi dikatakan cocok jika nilai Dn < D kritisnya pada derajat kepercayaan yang diinginkan. Urutan uji ini adalah sebagai berikut:

1. Susun data curah hujan harian rata-rata tiap tahun dari kecil ke besar atau sebaliknya;

2. Hitung probabilitas untuk masing-masing data hujan dengan persamaan Weibull

3. Cari harga mutlak perbedaan maksimum antara distribusi empiris ( $\mathrm{P}$ empiris) dengan distribusi teoritis ( $\mathrm{P}$ teoritis)

4. Apabila nilai $\Delta \leq \Delta$ kritis sesuai harga kritis uji Kolmogorov-Smirnov maka distribusi teoritisnya dapat diterima dan bila terjadi sebaliknya maka distribusi teoritisnya ditolak.

4. Distribusi Normal

Analisis hidrologi sering menggunakan distribusi normal untuk menganalisis frekuensi curah hujan, analisis statistik berdasarkan distribusi curah hujan tahunan, debit rata-rata tahunan. Sebaran normal atau kurva normal disebut juga sebagai sebaran Gauss. Rumus yang digunakan dalam perhitungan adalah:

$$
\mathrm{X}_{\mathrm{t}}=\overline{\mathrm{X}}+\mathrm{K}_{\mathrm{T}} \cdot S
$$

dengan $\mathrm{X}_{\mathrm{t}}=$ curah hujan rencana, $\overline{\mathrm{X}}=$ curah hujan maksimum rata-rata, $\mathrm{S}=$ standar deviasi dan $\mathrm{K}_{\mathrm{T}}=$ faktor frekuensi. Dengan nilai KT berdasarkan tabel faktor frekuensi/nilai variabel veduksi Gauss (Supriadi, 2008).

\section{Distribusi Log Normal}

Distribusi Log Normal, merupakan hasil transformasi dari distribusi normal, dengan mengubah varian X menjadi nilai logaritmik varian X. Rumus yang digunakan dalam perhitungan metode ini adalah sebagai berikut:

$$
\log \mathrm{X}_{\mathrm{t}}=\log \overline{\mathrm{X}}+\mathrm{K}_{\mathrm{T}} \cdot \mathrm{SLogX}
$$

dengan, $\log \mathrm{X}_{\mathrm{t}}=$ harga logaritmik curah hujan rencana, $\log \overline{\mathrm{X}}=$ harga rata-rata logaritmik dan $\mathrm{SLogX}=$ harga logaritmik standar deviasi

\section{Distribusi Gumbel}

Distribusi Gumbel digunakan untuk analisis data maksimum, sebagai contoh untuk analisis frekuensi banjir, dengan rumus sebagai berikut:

$$
\mathrm{X}_{\mathrm{t}}=\overline{\mathrm{x}}+\frac{\left(\mathrm{Y}_{\mathrm{t}}-\mathrm{Y}_{\mathrm{n}}\right)}{\mathrm{S}_{\mathrm{n}}} \times \mathbf{S}
$$

dengan $\mathrm{Yt}=$ Reiduced variable, parameter Gumbel untuk periode $\mathrm{T}$ tahun, $\mathrm{Yn}=$ Reduced mean, merupakan fungsi dari banyaknya data dan $\mathrm{Sn}=$ Reduced standar deviasi, merupakan fungsi dari banyak data.

Dengan nilai Yn dan Sn berdasarkan tabel Gumbel Hubungan n dengan Yn dan Sn (Suripin, 2004).

Distribusi Log Pearson Tipe - III

Sebaran Log Pearson tipe III merupakan hasil transformasi dari sebaran Pearson tipe III dengan menggantikan varian menjadi nilai logaritmik. Langkah-langkah perhitungannya adalah sebagai berikut (Soemarto, 1995):

1. Mengubah data curah hujan sebanyak $n$ buah $X 1, X 2, X 3, \ldots X n$ menjadi $\log (X 1), \log (X 2)$, $\log (\mathrm{X} 3), \ldots, \log (\mathrm{Xn})$.

2. Menghitung harga rata-ratanya dengan rumus :

$$
\log \overline{\mathrm{X}}=\frac{\sum_{\mathrm{i}=1}^{\mathrm{n}} \log \left(\mathrm{X}_{\mathrm{i}}\right)}{\mathrm{n}}
$$

dengan $\mathrm{n}=$ jumlah data

3. Menghitung logaritma hujan rencana dengan periode ulang $\mathrm{T}$ tahun dengan rumus: 


$$
\mathrm{S}=\sqrt{\frac{\sum_{\mathrm{i}=1}^{\mathrm{n}}\left\{\log \left(\mathrm{X}_{\mathrm{i}}\right)-\log (\overline{\mathrm{X}})\right\}^{2}}{\mathrm{n}-1}}
$$

4. Menghitung koefisien skewness (Cs) dengan rumus:

$$
\mathrm{C}_{\mathrm{s}}=\frac{\sum_{\mathrm{i}=1}^{\mathrm{n}}\left\{\log \left(\mathrm{X}_{\mathrm{i}}\right)-\log (\overline{\mathrm{X}})\right\}^{3}}{(\mathrm{n}-1)(\mathrm{n}-2) \mathrm{S}^{3}}
$$

dengan Cs = koefisien skewness

5. Menghitung logaritma hujan rencana dengan periode ulang $\mathrm{T}$ tahun dengan rumus:

$$
\begin{gathered}
\log Y=\log \bar{X}+k \cdot S \\
X_{t}=10^{(\log Y)}
\end{gathered}
$$

dengan $\mathrm{k}=$ harga yang diperoleh berdasarkan nilai Cs

\section{HEC-RAS}

HEC-RAS merupakan program aplikasi untuk memodelkan aliran air di sungai, River Analysis System (RAS). HECRAS merupakan model satu dimensi aliran permanen maupun tak permanen (Istiarto, 2014).Memiliki empat komponen model satu dimensi:

1. Hitungan profil muka air aliran permanen,

2. Simulasi aliran tak permanen,

3. Hitungan transpor sedimen, dan

4. Hitungan kualitas air.

Satu elemen penting dalam HEC-RAS adalah keempat komponen tersebut menggunakan data geometri yang sama, routine hitungan hidraulika yang sama, serta berbagai fitur desain hidraulik yang dapat diakses setelah hitungan profil muka air berhasil dilakukan.

\section{METODE PENELITIAN}

\section{Pengumpulan data}

Data-data yang diperlukan terdiri dari:

1. Peta Lokasi Kelurahan Tanjung Duren Selatan yang diambil dari Suku Dinas Tata Air Kota Jakarta Barat.

2. Peta Sebaran Titik Banjir di Kelurahan Tanjung Duren Selatan yang diambil dari Suku Dinas Tata Air Kota Jakarta Barat.

3. Data Curah Hujan dari Stasiun Meteorologi Kemayoran yang diambil dari Badan Meteorologi, Klimatologi, dan Geofisika.

4. Peta Jaringan Drainase di Kelurahan Tanjung Duren Selatan diambil dari Suku Dinas Tata Air Kota Jakarta Barat.

5. Spesifikasi saluran eksisting di Kelurahan Tanjung Duren Selatan diambil dari Suku Dinas Tata Air Kota Jakarta Barat serta pengukuran langsung di lapangan.

6. Peta Topografi di Kelurahan Tanjung Duren Selatan yang diambil dari Suku Dinas Tata Air Kota Jakarta Barat.

\section{Pengolahan data}

Berikut langkah-langkah pengolahan data yang dilakukan:

1. Mengolah data curah hujan yaitu dengan mengambil data curah hujan harian selama 10 tahun dari Stasiun Meteorologi Kemayoran menjadi curah hujan maksimum per tahun.

2. Melakukan pengujian kecocokan fungsi distribusi dengan metode Chi-Square dan Kolmogorov-Smirnov untuk menentukan distribusi yang digunakan

3. Menganalisa frekuensi curah hujan dengan menggunakan empat jenis distribusi yang digunakan dalam bidang hidrologi yaitu Distribusi Normal, Gumbel Tipe 1, Log Normal, dan metode Log Pearson Tipe 3 berdasarkan SNI 2415:2016.

4. Melakukan perhitungan intensitas hujan dengan rumus Mononobe.

5. Menentukan daerah tangkapan air dari masing-masing saluran drainase.

6. Menghitung kapasitas saluran eksisting drainase.

7. Menghitung debit rencana dengan metode rasional.

8. Menganalisis apakah debit saluran eksisting mampu menampung debit rencana atau tidak.

9. Menganalisis topografi dari wilayah yang terdampak banjir 


\section{HASIL DAN PEMBAHASAN}

Dari pengujian distribusi Chi-Square dan uji Kolmogorov-Smirnov berikut dapat disimpulkan bahwa data curah hujan yang dimiliki dianalisis dengan menggunakan metode distribusi Log Pearson Tipe III karena memiliki nilai kritis yang kecil. Hasil pengujian distribusi Chi-Square dan uji Kolmogorov-Smirnov dapat dilihat pada Tabel 1.

Tabel 1. Analisis distribusi

\begin{tabular}{ccccc}
\hline Metode Distribusi & \multicolumn{2}{c}{ Chi-Square } & \multicolumn{2}{c}{ Kolmogorov-Smirnov } \\
\hline Normal & $3<5,9915$ & Bisa Diterima & $0,1924<0,41$ & Bisa Diterima \\
Log Normal & $1<5,9915$ & Bisa Diterima & $0,1519<0,41$ & Bisa Diterima \\
Log Pearson Tipe III & $1<5,9915$ & Bisa Diterima & $0,1305<0,41$ & Bisa Diterima \\
Gumbel & $5<5,9915$ & Bisa Diterima & $0,1313<0,41$ & Bisa Diterima \\
\hline
\end{tabular}

Curah hujan rencana digunakan periode ulang 2 tahun karena luas daerah tangkapan kurang dari 10 ha (Menteri Pekerjaan Umum, 2014). Hasil perhitungan curah hujan yang dilakukan dapat dilihat pada Tabel 2.

Tabel 2. Hasil perhitungan curah hujan

\begin{tabular}{cccc}
\hline \multicolumn{3}{c}{$\begin{array}{c}\text { Menghitung Interval Kelas Distribusi Log } \\
\text { Pearson III }\end{array}$} \\
\hline \multicolumn{3}{c}{ Log X rata2 } & \multicolumn{2}{c}{2,1292} \\
s Log X & \multicolumn{2}{c}{0,1577} \\
\multicolumn{2}{c}{ Cs } & \multicolumn{2}{c}{0,8802} \\
$\mathrm{~T}$ & $\mathrm{Kt}$ & Log Xt & Xt \\
$\mathrm{T}=2$ & $-0,1448$ & 2,1064 & 127,7619 \\
$\mathrm{~T}=5$ & 0,7712 & 2,2508 & 178,1760 \\
$\mathrm{~T}=10$ & 1,3380 & 2,3402 & 218,8950 \\
$\mathrm{~T}=25$ & 2,0150 & 2,4470 & 279,8965 \\
\hline
\end{tabular}

Penamaan saluran tersier dan sekunder dapat dilihat pada Gambar 2.

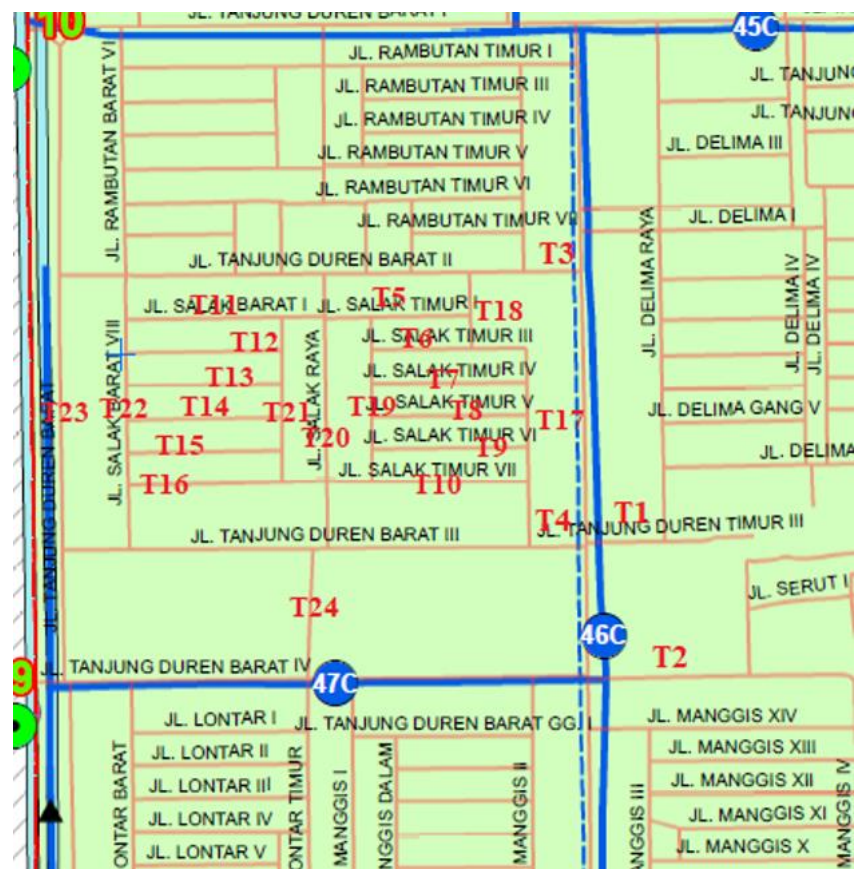

Gambar 2. Penamaan saluran 
Perhitungan kemiringan dasar saluran dengan perbedaan tinggi menggunakan data topografi dan pengukuran panjang saluran menggunakan data dari Suku Dinas Sumber Daya Air Kota Jakarta Barat serta bantuan dari Google Maps untuk membantu mengukur panjang saluran tersier dapat dilihat pada Tabel 3.

Tabel 3. Perhitungan kemiringan dasar saluran

\begin{tabular}{ccccc}
\hline \multirow{2}{*}{ Nama } & $\begin{array}{c}\text { Panjang } \\
(\mathrm{m})\end{array}$ & \multicolumn{2}{c}{ Tinggi $(\mathrm{m})$} & Kemiringan \\
& 920 & 3 & 2 & 0,00108696 \\
46C & 425 & 2 & 1,5 & 0,00117647 \\
47C & 125 & 2,2 & 2 & 0,0016 \\
T1 & 200 & 2,2 & 2 & 0,001 \\
T2 & 390 & 2 & 1,6 & 0,00102564 \\
T3, T4 & 100 & 2,2 & 2,1 & 0,001 \\
T5 & 115 & 2,2 & 2,1 & 0,00086957 \\
T6, T7, T8, T9 & 150 & 2,3 & 2,1 & 0,00133333 \\
T10 & 150 & 2,2 & 2 & 0,00133333 \\
T11 & 115 & 2,2 & 2 & 0,00173913 \\
T12, T13, T14, T15 & 150 & 2,2 & 2 & 0,00133333 \\
T16 & 160 & 2,3 & 2,2 & 0,000625 \\
T17 & 50 & 2 & 2 & 0,001 \\
T18 & 120 & 2,2 & 2 & 0,00166667 \\
T19, T21 & 205 & 2,3 & 2 & 0,00146341 \\
T20 & 205 & 2 & 1,8 & 0,001 \\
T22 & 205 & 2 & 1,8 & 0,001 \\
T23 & 95 & 2,4 & 2,3 & 0,00105263 \\
T24 & & & & \\
\hline & 2,3 & 2,3 & \\
\hline
\end{tabular}

Hasil perhitungan kapasitas saluran eksisting menggunakan rumus Manning dapat dilihat pada Tabel 4. Menggunakan koefisien kekasaran Manning 0,015 dengan jenis lapisan perkerasan beton seluruhnya (Haryono, 2016).

Tabel 4 Perhitungan kapasitas saluran eksisting

\begin{tabular}{llccccccc}
\hline \multirow{2}{*}{ Nama } & \multirow{2}{*}{ Panjang $(\mathrm{m})$} & \multicolumn{2}{c}{ Lebar $(\mathrm{m})$} & \multirow{2}{*}{ Dedalaman $(\mathrm{m})$} & Kemiringan & $\mathrm{V}(\mathrm{m} / \mathrm{s})$ & $\mathrm{Q}\left(\mathrm{m}^{3} / \mathrm{s}\right)$ \\
\hline 46C & Kanan & 920 & 2,00 & 2,00 & 1,00 & 0,0011 & 1,3846 & 2,7692 \\
46C & Kiri & 920 & 1,50 & 1,50 & 1,00 & 0,0011 & 1,2494 & 1,8741 \\
47C & Kanan & 425 & 1,20 & 1,20 & 1,00 & 0,0012 & 1,1891 & 1,4269 \\
47C & Kiri & 425 & 1,50 & 1,50 & 1,00 & 0,0012 & 1,2998 & 1,9497 \\
T1 & Kanan & 125 & 1,00 & 1,00 & 0,65 & 0,0016 & 1,1484 & 0,7465 \\
T1 & Kiri & 125 & 1,00 & 1,00 & 0,65 & 0,0016 & 1,1484 & 0,7465 \\
T2 & Kanan & 200 & 1,00 & 1,00 & 0,65 & 0,0010 & 0,9079 & 0,5901 \\
T2 & Kiri & 200 & 1,00 & 1,00 & 0,65 & 0,0010 & 0,9079 & 0,5901 \\
T3 & Kanan & 390 & 0,90 & 0,90 & 1,00 & 0,0010 & 0,9787 & 0,8808 \\
T3 & Kiri & 390 & 0,90 & 0,90 & 1,00 & 0,0010 & 0,9787 & 0,8808 \\
T4 & Kanan & 390 & 1,00 & 1,00 & 1,20 & 0,0010 & 1,0663 & 1,2795 \\
T4 & Kiri & 390 & 1,00 & 1,00 & 1,20 & 0,0010 & 1,0663 & 1,2795 \\
\hline
\end{tabular}


Tabel 4. Perhitungan kapasitas saluran eksisting (Lanjutan)

\begin{tabular}{|c|c|c|c|c|c|c|c|c|}
\hline Nam & & Paniano (m) & Lebai & (m) & Kedalaman (m) & Kemiringan & $\mathrm{V}(\mathrm{m} / \mathrm{s})$ & $\mathrm{O}\left(\mathrm{m}^{3} / \mathrm{s}\right)$ \\
\hline & & & Dasar & Atas & & & $v(111 / \mathrm{s})$ & \\
\hline $\mathrm{T} 5$ & Kanan & 100 & 0,60 & 0,60 & 0,50 & 0,0010 & 0,6906 & 0,2072 \\
\hline T5 & Kiri & 100 & 0,60 & 0,60 & 0,50 & 0,0010 & 0,6906 & 0,2072 \\
\hline T6 & Kanan & 115 & 0,70 & 0,70 & 0,50 & 0,0009 & 0,6854 & 0,2399 \\
\hline T6 & Kiri & 115 & 0,70 & 0,70 & 0,50 & 0,0009 & 0,6854 & 0,2399 \\
\hline $\mathrm{T} 7$ & Kanan & 115 & 0,70 & 0,70 & 0,50 & 0,0009 & 0,6854 & 0,2399 \\
\hline $\mathrm{T} 7$ & Kiri & 115 & 0,70 & 0,70 & 0,50 & 0,0009 & 0,6854 & 0,2399 \\
\hline $\mathrm{T} 8$ & Kanan & 115 & 0,70 & 0,70 & 0,50 & 0,0009 & 0,6854 & 0,2399 \\
\hline $\mathrm{T} 8$ & Kiri & 115 & 0,70 & 0,70 & 0,50 & 0,0009 & 0,6854 & 0,2399 \\
\hline T9 & Kanan & 115 & 0,70 & 0,70 & 0,50 & 0,0009 & 0,6854 & 0,2399 \\
\hline T9 & Kiri & 115 & 0,70 & 0,70 & 0,50 & 0,0009 & 0,6854 & 0,2399 \\
\hline $\mathrm{T} 10$ & Kanan & 150 & 0,60 & 0,60 & 0,50 & 0,0013 & 0,7975 & 0,2392 \\
\hline $\mathrm{T} 10$ & Kiri & 150 & 0,60 & 0,60 & 0,50 & 0,0013 & 0,7975 & 0,2392 \\
\hline T11 & Kanan & 150 & 0,60 & 0,60 & 0,50 & 0,0013 & 0,7975 & 0,2392 \\
\hline $\mathrm{T} 11$ & Kiri & 150 & 0,60 & 0,60 & 0,50 & 0,0013 & 0,7975 & 0,2392 \\
\hline $\mathrm{T} 12$ & Kanan & 115 & 0,70 & 0,70 & 0,50 & 0,0017 & 0,9694 & 0,3393 \\
\hline $\mathrm{T} 12$ & Kiri & 115 & 0,70 & 0,70 & 0,50 & 0,0017 & 0,9694 & 0,3393 \\
\hline T13 & Kanan & 115 & 0,70 & 0,70 & 0,50 & 0,0017 & 0,9694 & 0,3393 \\
\hline T13 & Kiri & 115 & 0,70 & 0,70 & 0,50 & 0,0017 & 0,9694 & 0,3393 \\
\hline T14 & Kanan & 115 & 0,70 & 0,70 & 0,50 & 0,0017 & 0,9694 & 0,3393 \\
\hline $\mathrm{T} 14$ & Kiri & 115 & 0,70 & 0,70 & 0,50 & 0,0017 & 0,9694 & 0,3393 \\
\hline $\mathrm{T} 15$ & Kanan & 115 & 0,70 & 0,70 & 0,50 & 0,0017 & 0,9694 & 0,3393 \\
\hline $\mathrm{T} 15$ & Kiri & 115 & 0,70 & 0,70 & 0,50 & 0,0017 & 0,9694 & 0,3393 \\
\hline T16 & Kanan & 150 & 0,60 & 0,60 & 0,50 & 0,0013 & 0,7975 & 0,2392 \\
\hline T16 & Kiri & 150 & 0,60 & 0,60 & 0,50 & 0,0013 & 0,7975 & 0,2392 \\
\hline $\mathrm{T} 17$ & Kanan & 160 & 0,70 & 0,70 & 0,60 & 0,0006 & 0,6093 & 0,2559 \\
\hline $\mathrm{T} 17$ & Kiri & 160 & 0,70 & 0,70 & 0,60 & 0,0006 & 0,6093 & 0,2559 \\
\hline $\mathrm{T} 18$ & Kiri & 50 & 0,40 & 0,40 & 0,40 & 0,0010 & 0,5502 & 0,0880 \\
\hline T19 & Kanan & 120 & 0,70 & 0,70 & 0,60 & 0,0017 & 0,9950 & 0,4179 \\
\hline T19 & Kiri & 120 & 0,70 & 0,70 & 0,60 & 0,0017 & 0,9950 & 0,4179 \\
\hline $\mathrm{T} 20$ & Kanan & 205 & 0,70 & 0,70 & 0,70 & 0,0015 & 0,9666 & 0,4736 \\
\hline $\mathrm{T} 20$ & Kiri & 205 & 0,70 & 0,70 & 0,70 & 0,0015 & 0,9666 & 0,4736 \\
\hline $\mathrm{T} 21$ & Kanan & 120 & 0,70 & 0,70 & 0,60 & 0,0017 & 0,9950 & 0,4179 \\
\hline $\mathrm{T} 21$ & Kiri & 120 & 0,70 & 0,70 & 0,60 & 0,0017 & 0,9950 & 0,4179 \\
\hline $\mathrm{T} 22$ & Kanan & 205 & 0,70 & 0,70 & 0,60 & 0,0010 & 0,7707 & 0,3237 \\
\hline $\mathrm{T} 22$ & Kiri & 205 & 0,70 & 0,70 & 0,60 & 0,0010 & 0,7707 & 0,3237 \\
\hline $\mathrm{T} 23$ & Kanan & 205 & 0,60 & 0,60 & 0,80 & 0,0010 & 0,7640 & 0,3667 \\
\hline
\end{tabular}

Perhitungan intensitas hujan menggunakan rumus Mononobe dengan periode ulang 2 tahun dan debit rencana menggunakan metode rasional karena luas pengaliran tidak lebih dari 5000 ha, dapat dilihat pada Tabel 5. Luas daerah tangkapan didapat dari pengukuran luas lahan berdasarkan arah aliran pada dengan menggunakan aplikasi Google Maps berdasarkan Gambar 3 yang didapat dari pengamatan langsung di lapangan. 


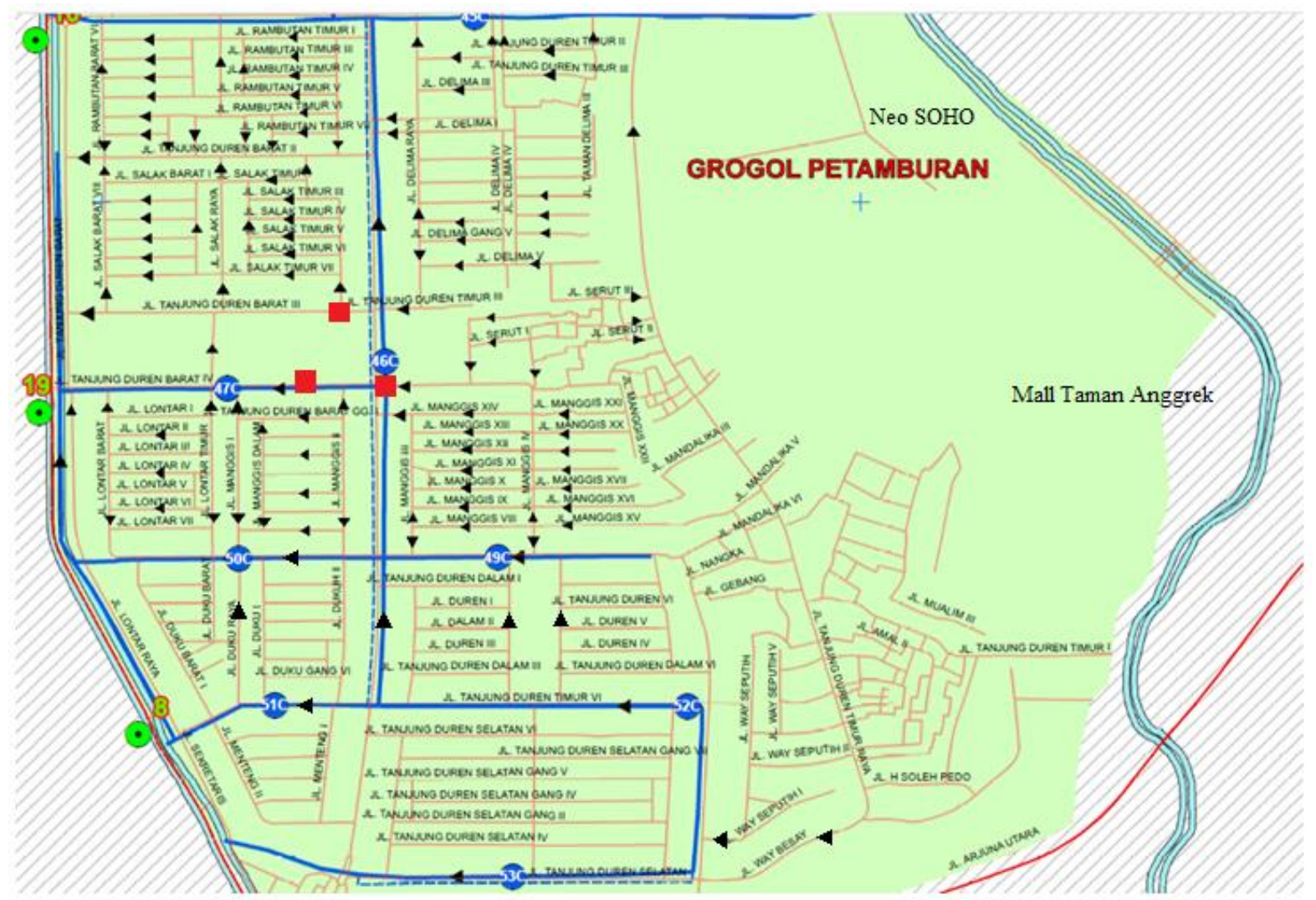

Gambar 3. Arah aliran saluran

Tabel 5. Perhitungan intensitas hujan dan debit rencana

\begin{tabular}{llcccccc}
\hline \multicolumn{2}{c}{ Nama } & Panjang $(\mathrm{m})$ & $\mathrm{V}(\mathrm{m} / \mathrm{s})$ & tc $(\mathrm{jam})$ & $\begin{array}{c}\mathrm{T}=2 \\
127,7619\end{array}$ & Area $\left(\mathrm{m}^{2}\right)$ & Q Rencana $\left(\mathrm{m}^{3} / \mathrm{s}\right)$ \\
\hline 46C & Kanan & 920 & 1,3846 & 0,3679 & 86,2667 & 253800 & 4,5650 \\
46C & Kiri & 920 & 1,2494 & 0,2679 & 106,5875 & 22000 & 0,4889 \\
47C & Kanan & 425 & 1,1891 & 0,1843 & 136,7762 & 16700 & 0,4762 \\
47C & Kiri & 425 & 1,2998 & 0,2242 & 120,0313 & 71430 & 1,7876 \\
T1 & Kanan & 125 & 1,1484 & 0,1469 & 159,0911 & 23000 & 0,7629 \\
T1 & Kiri & 125 & 1,1484 & 0,1469 & 159,0911 & 10800 & 0,3582 \\
T2 & Kanan & 200 & 0,9079 & 0,1479 & 158,4041 & 18750 & 0,6193 \\
T2 & Kiri & 200 & 0,9079 & 0,1945 & 131,9310 & 48000 & 1,3204 \\
T3 & Kanan & 390 & 0,9787 & 0,1607 & 149,8524 & 21100 & 0,6593 \\
T3 & Kiri & 390 & 0,9787 & 0,2440 & 113,4239 & 7600 & 0,1797 \\
T4 & Kanan & 390 & 1,0663 & 0,1883 & 134,8396 & 11250 & 0,3163 \\
T4 & Kiri & 390 & 1,0663 & 0,1883 & 134,8396 & 18500 & 0,5201 \\
T5 & Kanan & 100 & 0,6906 & 0,1913 & 133,4014 & 1100 & 0,0306 \\
T5 & Kiri & 100 & 0,6906 & 0,1913 & 133,4014 & 17000 & 0,4728 \\
T6 & Kanan & 115 & 0,6854 & 0,1112 & 191,5497 & 1500 & 0,0599 \\
T6 & Kiri & 115 & 0,6854 & 0,1112 & 191,5497 & 1800 & 0,0719 \\
T7 & Kanan & 115 & 0,6854 & 0,1112 & 191,5497 & 1340 & 0,0535 \\
T7 & Kiri & 115 & 0,6854 & 0,1112 & 191,5497 & 1500 & 0,0599 \\
\hline
\end{tabular}


Tabel 5. Perhitungan intensitas hujan dan debit rencana (Lanjutan)

\begin{tabular}{|c|c|c|c|c|c|c|c|}
\hline \multicolumn{2}{|c|}{ Nama } & \multirow{2}{*}{$\begin{array}{c}\text { Panjang (m) } \\
115\end{array}$} & \multirow{2}{*}{$\begin{array}{c}\mathrm{V}(\mathrm{m} / \mathrm{s}) \\
0,6854\end{array}$} & \multirow{2}{*}{$\begin{array}{l}\text { tc (jam) } \\
0,1112\end{array}$} & \multirow{2}{*}{$\begin{array}{c}\mathrm{T}=2 \\
127,7619 \\
191,5497\end{array}$} & \multirow{2}{*}{$\frac{\text { Area }\left(\mathrm{m}^{2}\right)}{1415}$} & \multirow{2}{*}{$\frac{\text { Q Rencana }\left(\mathrm{m}^{3} / \mathrm{s}\right)}{0,0565}$} \\
\hline T8 & Kanan & & & & & & \\
\hline $\mathrm{T} 8$ & Kiri & 115 & 0,6854 & 0,1112 & 191,5497 & 1200 & 0,0479 \\
\hline T9 & Kanan & 115 & 0,6854 & 0,1112 & 191,5497 & 1300 & 0,0519 \\
\hline Т9 & Kiri & 115 & 0,6854 & 0,1112 & 191,5497 & 1650 & 0,0659 \\
\hline $\mathrm{T} 10$ & Kanan & 150 & 0,7975 & 0,1241 & 177,9961 & 2000 & 0,0742 \\
\hline $\mathrm{T} 10$ & Kiri & 150 & 0,7975 & 0,1241 & 177,9961 & 2220 & 0,0824 \\
\hline $\mathrm{T} 11$ & Kanan & 150 & 0,7975 & 0,1022 & 202,5624 & 1800 & 0,0760 \\
\hline $\mathrm{T} 11$ & Kiri & 150 & 0,7975 & 0,1022 & 202,5624 & 1800 & 0,0760 \\
\hline $\mathrm{T} 12$ & Kanan & 115 & 0,9694 & 0,0897 & 221,1148 & 1800 & 0,0830 \\
\hline $\mathrm{T} 12$ & Kiri & 115 & 0,9694 & 0,0897 & 221,1148 & 1800 & 0,0830 \\
\hline T13 & Kanan & 115 & 0,9694 & 0,0897 & 221,1148 & 1800 & 0,0830 \\
\hline $\mathrm{T} 13$ & Kiri & 115 & 0,9694 & 0,0897 & 221,1148 & 1800 & 0,0830 \\
\hline $\mathrm{T} 14$ & Kanan & 115 & 0,9694 & 0,0897 & 221,1148 & 1800 & 0,0830 \\
\hline $\mathrm{T} 14$ & Kiri & 115 & 0,9694 & 0,0897 & 221,1148 & 1800 & 0,0830 \\
\hline $\mathrm{T} 15$ & Kanan & 115 & 0,9694 & 0,0897 & 221,1148 & 1800 & 0,0830 \\
\hline $\mathrm{T} 15$ & Kiri & 115 & 0,9694 & 0,0897 & 221,1148 & 1800 & 0,0830 \\
\hline T16 & Kanan & 150 & 0,7975 & 0,1022 & 202,5624 & 2000 & 0,0845 \\
\hline T16 & Kiri & 150 & 0,7975 & 0,1022 & 202,5624 & 2000 & 0,0845 \\
\hline $\mathrm{T} 17$ & Kanan & 160 & 0,6093 & 0,1229 & 179,1430 & 2000 & 0,0747 \\
\hline $\mathrm{T} 17$ & Kiri & 160 & 0,6093 & 0,1229 & 179,1430 & 1000 & 0,0374 \\
\hline T18 & Kiri & 50 & 0,5502 & 0,3767 & 84,9234 & 3000 & 0,0531 \\
\hline T19 & Kanan & 120 & 0,9950 & 0,1472 & 158,8895 & 13600 & 0,4505 \\
\hline T19 & Kiri & 120 & 0,9950 & 0,1472 & 158,8895 & 1940 & 0,0643 \\
\hline $\mathrm{T} 20$ & Kanan & 205 & 0,9666 & 0,1830 & 137,3919 & 26600 & 0,7620 \\
\hline $\mathrm{T} 20$ & Kiri & 205 & 0,9666 & 0,1089 & 194,2133 & 3600 & 0,1458 \\
\hline $\mathrm{T} 21$ & Kanan & 120 & 0,9950 & 0,0940 & 214,3218 & 1380 & 0,0617 \\
\hline $\mathrm{T} 21$ & Kiri & 120 & 0,9950 & 0,0940 & 214,3218 & 1100 & 0,0492 \\
\hline $\mathrm{T} 22$ & Kanan & 205 & 0,7707 & 0,1761 & 140,9631 & 22000 & 0,6466 \\
\hline $\mathrm{T} 22$ & Kiri & 205 & 0,7707 & 0,1761 & 140,9631 & 2500 & 0,0735 \\
\hline $\mathrm{T} 23$ & Kanan & 205 & 0,7640 & 0,1245 & 177,6160 & 4750 & 0,1759 \\
\hline
\end{tabular}

Perbandingan antara debit rencana dengan kapasitas saluran eksisting, serta mengetahui rancangan saluran eksisting yang ada dirancang untuk menampung debit rencana periode ulang 2 tahun dapat dilihat pada Tabel 6.

Tabel 6. Perbandingan debit rencana dan eksisting

\begin{tabular}{llccc}
\hline \multicolumn{2}{c}{ Nama } & Q Rencana $\left(\mathrm{m}^{3} / \mathrm{s}\right)$ & Q Eksisting $\left(\mathrm{m}^{3} / \mathrm{s}\right)$ & Kesimpulan \\
\hline 46C & Kanan & 4,5650 & 2,7692 & BANJIR \\
46C & Kiri & 0,4889 & 1,8741 & AMAN \\
47C & Kanan & 0,4762 & 1,4269 & AMAN \\
47C & Kiri & 1,7876 & 1,9497 & AMAN \\
\hline
\end{tabular}


Tabel 6. Perbandingan debit rencana dan eksisting (Lanjutan)

\begin{tabular}{|c|c|c|c|c|}
\hline Nama & & Q Rencana $\left(\mathrm{m}^{3} / \mathrm{s}\right)$ & Q Eksisting $\left(\mathrm{m}^{3} / \mathrm{s}\right)$ & Kesimpulan \\
\hline $\mathrm{T} 1$ & Kanan & 0,7629 & 0,7465 & BANJIR \\
\hline $\mathrm{T} 1$ & Kiri & 0,3582 & 0,7465 & AMAN \\
\hline $\mathrm{T} 2$ & Kanan & 0,6193 & 0,5901 & BANJIR \\
\hline $\mathrm{T} 2$ & Kiri & 1,3204 & 0,5901 & BANJIR \\
\hline $\mathrm{T} 3$ & Kanan & 0,6593 & 0,8808 & AMAN \\
\hline $\mathrm{T} 3$ & Kiri & 0,1797 & 0,8808 & AMAN \\
\hline $\mathrm{T} 4$ & Kanan & 0,3163 & 1,2795 & AMAN \\
\hline $\mathrm{T} 4$ & Kiri & 0,5201 & 1,2795 & AMAN \\
\hline T5 & Kanan & 0,0306 & 0,2072 & AMAN \\
\hline T5 & Kiri & 0,4728 & 0,2072 & BANJIR \\
\hline T6 & Kanan & 0,0599 & 0,2399 & AMAN \\
\hline T6 & Kiri & 0,0719 & 0,2399 & AMAN \\
\hline $\mathrm{T} 7$ & Kanan & 0,0535 & 0,2399 & AMAN \\
\hline $\mathrm{T} 7$ & Kiri & 0,0599 & 0,2399 & AMAN \\
\hline $\mathrm{T} 8$ & Kanan & 0,0565 & 0,2399 & AMAN \\
\hline $\mathrm{T} 8$ & Kiri & 0,0479 & 0,2399 & AMAN \\
\hline T9 & Kanan & 0,0519 & 0,2399 & AMAN \\
\hline Т9 & Kiri & 0,0659 & 0,2399 & AMAN \\
\hline $\mathrm{T} 10$ & Kanan & 0,0742 & 0,2392 & AMAN \\
\hline $\mathrm{T} 10$ & Kiri & 0,0824 & 0,2392 & AMAN \\
\hline T11 & Kanan & 0,0760 & 0,2392 & AMAN \\
\hline $\mathrm{T} 11$ & Kiri & 0,0760 & 0,2392 & AMAN \\
\hline $\mathrm{T} 12$ & Kanan & 0,0830 & 0,3393 & AMAN \\
\hline $\mathrm{T} 12$ & Kiri & 0,0830 & 0,3393 & AMAN \\
\hline $\mathrm{T} 13$ & Kanan & 0,0830 & 0,3393 & AMAN \\
\hline $\mathrm{T} 13$ & Kiri & 0,0830 & 0,3393 & AMAN \\
\hline $\mathrm{T} 14$ & Kanan & 0,0830 & 0,3393 & AMAN \\
\hline $\mathrm{T} 14$ & Kiri & 0,0830 & 0,3393 & AMAN \\
\hline $\mathrm{T} 15$ & Kanan & 0,0830 & 0,3393 & AMAN \\
\hline $\mathrm{T} 15$ & Kiri & 0,0830 & 0,3393 & AMAN \\
\hline T16 & Kanan & 0,0845 & 0,2392 & AMAN \\
\hline T16 & Kiri & 0,0845 & 0,2392 & AMAN \\
\hline $\mathrm{T} 17$ & Kanan & 0,0747 & 0,2559 & AMAN \\
\hline $\mathrm{T} 17$ & Kiri & 0,0374 & 0,2559 & AMAN \\
\hline T18 & Kiri & 0,0531 & 0,0880 & AMAN \\
\hline T19 & Kanan & 0,4505 & 0,4179 & BANJIR \\
\hline T19 & Kiri & 0,0643 & 0,4179 & AMAN \\
\hline $\mathrm{T} 20$ & Kanan & 0,7620 & 0,4736 & BANJIR \\
\hline $\mathrm{T} 20$ & Kiri & 0,1458 & 0,4736 & AMAN \\
\hline $\mathrm{T} 21$ & Kanan & 0,0617 & 0,4179 & AMAN \\
\hline $\mathrm{T} 21$ & Kiri & 0,0492 & 0,4179 & AMAN \\
\hline $\mathrm{T} 22$ & Kanan & 0,6466 & 0,3237 & BANJIR \\
\hline $\mathrm{T} 22$ & Kiri & 0,0735 & 0,3237 & AMAN \\
\hline $\mathrm{T} 23$ & Kanan & 0,1759 & 0,3667 & AMAN \\
\hline
\end{tabular}


Dikarenakan kurangnya kapasitas saluran eksisting yang ada maka diperlukan perubahan dimensi saluran guna menambah kapasitas debit saluran tersebut. Dengan menggunakan metode Trial and Error maka didapat dimensi yang dapat dilihat pada Tabel 7.

Tabel 7. Perhitungan debit eksisting dengan dimensi baru

\begin{tabular}{llccccccc}
\hline \multicolumn{2}{c}{ Nama } & Panjang $(\mathrm{m})$ & \multicolumn{2}{c}{ Lebar $(\mathrm{m})$} & & & & \\
& & & Dasar & Atas & & & & \\
46C & Kanan & 920 & 3,30 & 3,30 & 1,20 & 0,0011 & 1,5686 & 4,9175 \\
T1 & Kanan & 125 & 1,10 & 1,10 & 0,85 & 0,0016 & 1,1895 & 0,8505 \\
T2 & Kanan & 200 & 1,10 & 1,10 & 0,85 & 0,0010 & 0,9404 & 0,6724 \\
T2 & Kiri & 200 & 1,90 & 1,90 & 0,85 & 0,0010 & 1,1175 & 1,3801 \\
T5 & Kiri & 100 & 1,40 & 1,40 & 0,60 & 0,0010 & 0,8467 & 0,4742 \\
T19 & Kanan & 120 & 0,90 & 0,90 & 0,70 & 0,0017 & 1,0419 & 0,4688 \\
T20 & Kanan & 205 & 1,20 & 1,20 & 0,80 & 0,0015 & 1,1429 & 0,8229 \\
T22 & Kanan & 205 & 1,50 & 1,50 & 0,70 & 0,0010 & 0,9448 & 0,7086 \\
\hline
\end{tabular}

Perbandingan dimensi saluran eksisting dengan saran dimensi saluran baru dapat dilihat pada Tabel 8.

Tabel 8. Perbandingan dimensi saluran lama dan baru

\begin{tabular}{|c|c|c|c|c|c|c|c|c|}
\hline \multirow{2}{*}{\multicolumn{2}{|c|}{ Nama }} & \multirow{3}{*}{$\begin{array}{c}\text { Panjang (m) } \\
920\end{array}$} & \multicolumn{3}{|c|}{ Dimensi Baru } & \multicolumn{3}{|c|}{ Dimensi Lama } \\
\hline & & & \multicolumn{2}{|c|}{ Lebar (m) } & \multirow{2}{*}{$\frac{\operatorname{Kedalaman}(\mathrm{m})}{1,20}$} & \multicolumn{2}{|c|}{ Lebar (m) } & \multirow{2}{*}{$\frac{\text { Kedalaman }(\mathrm{m})}{1,00}$} \\
\hline $46 \mathrm{C}$ & Kanan & & 3,30 & 3,30 & & 2,00 & 2,00 & \\
\hline $\mathrm{T} 1$ & Kanan & 125 & 1,10 & 1,10 & 0,85 & 1,00 & 1,00 & 0,65 \\
\hline $\mathrm{T} 2$ & Kanan & 200 & 1,10 & 1,10 & 0,85 & 1,00 & 1,00 & 0,65 \\
\hline $\mathrm{T} 2$ & Kiri & 200 & 1,90 & 1,90 & 0,85 & 1,00 & 1,00 & 0,65 \\
\hline T5 & Kiri & 100 & 1,40 & 1,40 & 0,60 & 0,60 & 0,60 & 0,50 \\
\hline $\mathrm{T} 19$ & Kanan & 120 & 0,90 & 0,90 & 0,70 & 0,70 & 0,70 & 0,60 \\
\hline T20 & Kanan & 205 & 1,20 & 1,20 & 0,80 & 0,70 & 0,70 & 0,70 \\
\hline $\mathrm{T} 22$ & Kanan & 205 & 1,50 & 1,50 & 0,70 & 0,70 & 0,70 & 0,60 \\
\hline
\end{tabular}

Perbandingan debit dimensi saluran baru dengan debit rencana dapat dilihat pada Tabel 9.

Tabel 9. Perbandingan debit eksisting dengan debit dimensi baru

\begin{tabular}{llccccccc}
\hline \multicolumn{2}{c}{ Nama } & $\begin{array}{c}\text { Panjang } \\
(\mathrm{m})\end{array}$ & $\begin{array}{c}\mathrm{V} \\
(\mathrm{m} / \mathrm{s})\end{array}$ & tc (jam) & $\begin{array}{c}\mathrm{T}=2 \\
127,7619\end{array}$ & $\begin{array}{c}\text { Q Rencana } \\
\left(\mathrm{m}^{3} / \mathrm{s}\right)\end{array}$ & $\begin{array}{c}\text { Q Eksisting } \\
\left(\mathrm{m}^{3} / \mathrm{s}\right)\end{array}$ & Kesimpulan \\
\hline 46C & Kanan & 920 & 1,5686 & 0,3463 & 89,8255 & 4,7533 & 4,9175 & AMAN \\
T1 & Kanan & 125 & 1,1895 & 0,1459 & 159,8499 & 0,7666 & 0,8505 & AMAN \\
T2 & Kanan & 200 & 0,9404 & 0,1457 & 159,9325 & 0,6252 & 0,6724 & AMAN \\
T2 & Kiri & 200 & 1,1175 & 0,1830 & 137,3903 & 1,3750 & 1,3801 & AMAN \\
T5 & Kiri & 100 & 0,8467 & 0,1913 & 133,4014 & 0,4728 & 0,4742 & AMAN \\
T19 & Kanan & 120 & 1,0419 & 0,1457 & 159,9827 & 0,4536 & 0,4688 & AMAN \\
T20 & Kanan & 205 & 1,1429 & 0,1740 & 142,1363 & 0,7883 & 0,8229 & AMAN \\
T22 & Kanan & 205 & 0,9448 & 0,1625 & 148,7265 & 0,6822 & 0,7086 & AMAN \\
\hline
\end{tabular}


Permodelan saluran T20 Kanan eksisting dan saluran dimensi baru menggunakan aplikasi HEC-RAS dapat dilihat pada Gambar 4 dan Gambar 5.

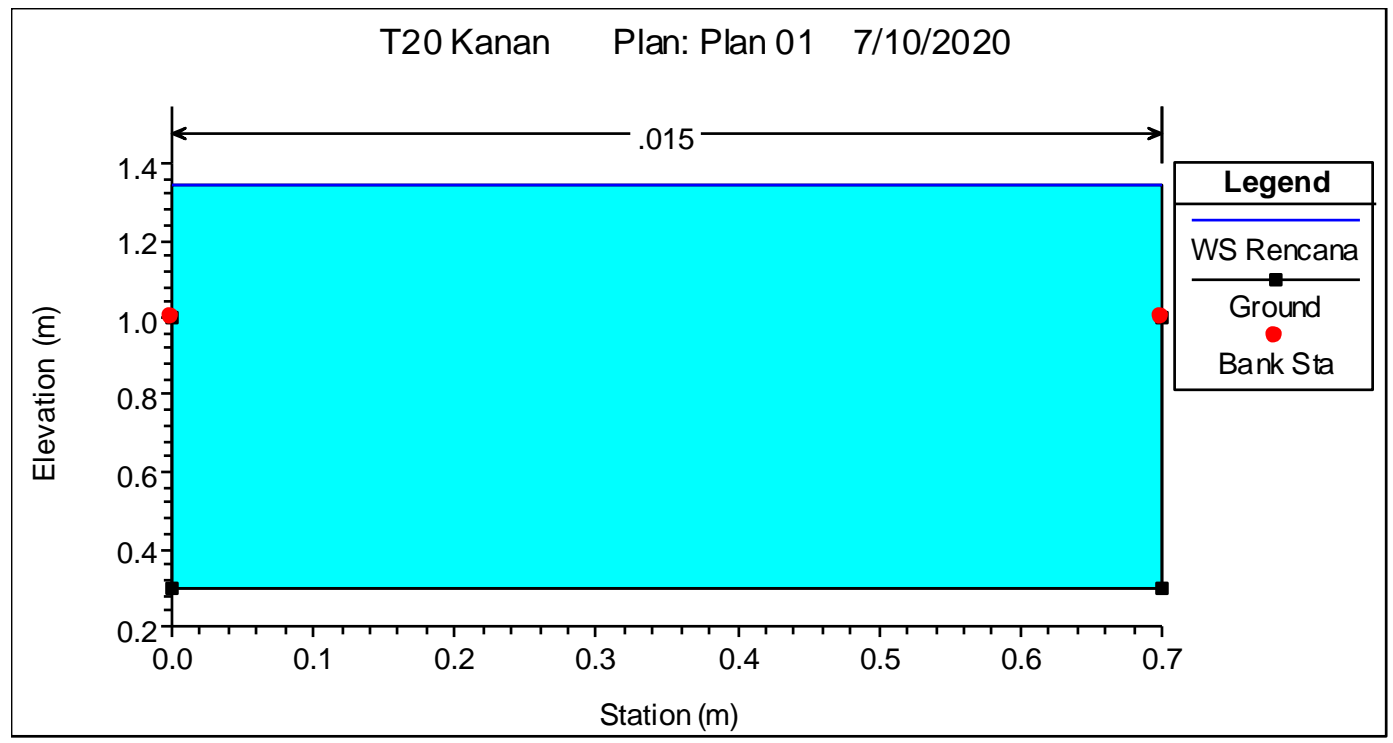

Gambar 4. Permodelan muka air saluran eksisting T20 Kanan hulu

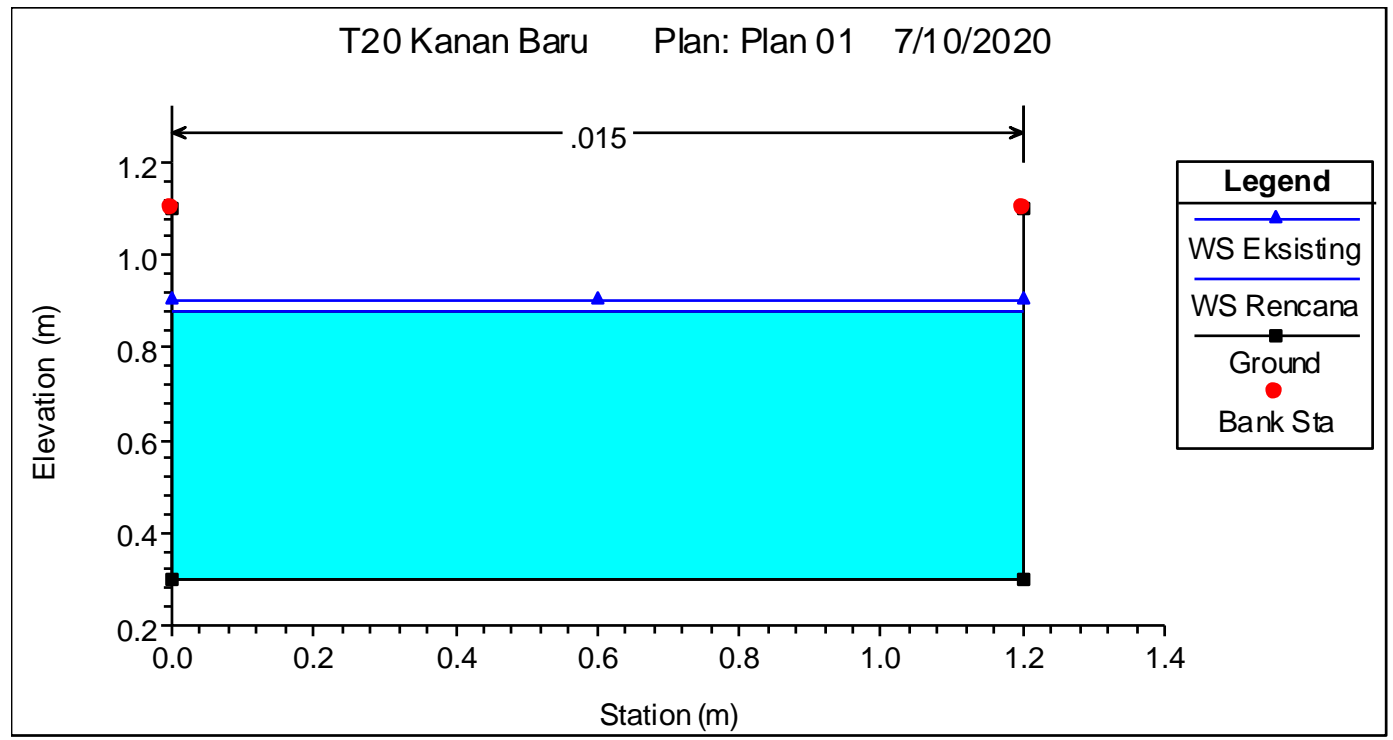

Gambar 5. Permodelan muka air saluran T20 Kanan hulu baru

\section{KESIMPULAN DAN SARAN}

\section{Kesimpulan}

Berdasarkan hasil analisis, 8 dari 48 saluran tidak mampu menampung kapasitas rencana periode ulang 2 tahun dengan perbedaan debit dapat di lihat pada Tabel 6.

Berdasarkan pengamatan langsung di lapangan penyebab lain selain kapasitas drainase adalah banyaknya sampah plastik seperti pada saluran T2 sehingga menghambat aliran air. Selain itu ada juga faktor topografi yang mempengaruhi letak genangan air.

\section{Saran}

Berdasarkan hasil analisis yang telah dilakukan disarankan adanya pembesaran dimensi saluran seperti pada Tabel 7. Disarankan juga untuk melakukan pembersihan saluran secara berkala. 
Penelitian ini masih terdapat kekurangan akibat minimnya data yang didapat dari jaringan saluran serta curah hujan. Disarankan untuk penelitian kedepannya menggunakan theodolite untuk pengukuran kemiringan dasar saluran, menggunakan dimensi saluran dari lembaga resmi, serta menggunakan data dari stasiun hujan yang lebih mendekati daerah tinjauan.

\section{DAFTAR PUSTAKA}

Badan Standarisasi Nasional. SNI 2415:2016 (Tata Cara Perhitungan Debit Banjir Recana). Jakarta: Badan Standardisasi Nasional, 2016.

Haryono, Yosef. Drainase. Jakarta: Jurusan Teknik Sipil-Fakultas Teknik Universitas Tarumanagara, 2016.

Istiarto. "Simulasi aliran 1-dimensi dengan bantuan paket program hidrodinamika HEC-RAS." Departemen Teknik Sipil dan Lingkungan Fakultas Teknik UGM (2014).

Menteri Pekerjaan Umum. "Peraturan Menteri Pekerjaan Umum Nomor 12/PRT/M/2014." (2014).

Supriadi. "Analisis Genangan Air Pada Prasarana Jalan dan Kaitannya Dengan Pengembangan Wilayah Di Kota Medan." University of Sumatera Utara Institutional Repository (2008): 10.

Suripin. Sistem Drainase Yang Berkelanjutan. Yogyakarta: Andi, 2004. 
